DOI:10.17951/h.2019.53.2.37-44

\begin{tabular}{lc}
\hline & A N N A L E S \\
UNIVERSITATIS MARIAE CURIE-SKŁODOWSKA \\
LUBLIN - POLONIA \\
SOL. LIII, 2
\end{tabular}

\author{
ANETA KARASEK \\ aneta.karasek@umcs.pl \\ Maria Curie-Skłodowska University in Lublin, Faculty of Economics \\ pl. Marii Curie-Skłodowskiej 5, 20-031 Lublin, Poland \\ ORCID ID: https://orcid.org/0000-0002-6055-5150
}

\title{
The use of information technology in human resource management in American enterprises
}

Keywords: IT technology; HRM; high-tech; IT solutions; recruitment; employee development

JEL: M12; M15; M54

How to quote this paper: Karasek, A. (2019). The use of information technology in human resource management in American enterprises. Annales Universitatis Mariae Curie-Skłodowska, sectio HOeconomia, Vol. 53, No. 2.

\footnotetext{
Abstract

Theoretical background: The ongoing development of information technology (IT) has caused IT solutions to be increasingly applied in human resource management (HRM). The implementation of such solutions is highly advantageous to enterprises because they streamline the provision of services to job candidates and employees, and save time and money. This is particularly important for high-tech enterprises using the latest scientific and technological advances and innovative solutions.

Purpose of the article: The objective of the study was to examine the use of IT tools in recruitment and selection, development and training, motivation, talent management and personnel services.

Research methods: The research employed the case study method. Documentation analysis, interview techniques and observations were carried out in enterprises. The paper describes three case studies of hightech companies headquartered in Silicon Valley in the United States.

Main findings: High-tech enterprises in Silicon Valley deploy a wide range of IT tools for recruitment and selection, development and training, motivation, talent management and human resource (HR) services, thus supporting personnel management processes and increasing the efficiency of administrative tasks. The type and scope of the applied IT solutions depended on the size of the company. Large enterprises had a tendency to integrate specific tools used in HR processes into one employee management system. The
} 
research showed a number of advantages regarding IT tool implementation in HRM, such as improved HR management efficiency due to data integration, obtaining a better match between employee competences, their development capacities and company demands. Moreover, the use of IT tools increased employee engagement in the performance of tasks. The implementation of IT tools in HRM produces certain limitations since technologies can be static and information can be transferred in one direction only. Therefore, faceto-face relationships, opportunities for sharing opinions between employees and prospects for development are essential in enterprises because they impact employee engagement.

\section{Introduction}

The rapidly growing number of information and communication technologies impacts the development and functioning of businesses. We have recently observed an increase in the use of information and mobile technologies (Chmielarz \& Parys, 2018, p. 17) by society. This has impacted human resource management (HRM) styles in different enterprises. In the United States, HRM has been undergoing a transformation to keep pace with economic changes and employee needs (Kaufman, 2014, pp. 196-218). Factors influencing the implementation of these solutions can be found in technology, organisations and people (Bondarouk et al., 2017, p. 98). The implementation of information technology (IT) solutions improves the provision of services for job candidates, employees and managers, and reduces administrative costs. In addition, the time spent by human resource (HR) department employees on administrative tasks is reduced and the above-mentioned solutions enable them to undertake strategic activities related to employee management, empower managers through the development and support of their management skills and improve the talent management process (Bondarouk \& Ruël, 2013, p. 392). This is particularly significant for enterprises operating in the high technology sector using the latest scientific and technological advances. In high-tech enterprises, this is mainly visible in inter-organisational networks because the latest technologies require close cooperation (Zakrzewska-Bielawska, 2015, p. 440). Therefore, it is necessary to have tools that support the implementation of HR processes and provide data for the implementation of strategic activities. The largest number of high-tech companies have been headquartered in Silicon Valley (USA). These enterprises not only understand new opportunities (and threats) easily, but they also embrace opportunities and carry out necessary changes when their new successful development becomes threatened (Steiber \& Alänge, 2016, s.v). This requires tools that enable the employees to meet the demanded requirements.

The review of the literature reveals a wide variety of IT solutions applied by companies in different areas of HRM. Due to an increasing demand for highly qualified staff and high-quality employee services, along with the need to engage employees in strategic measures, it is necessary to identify and assess the implementation of IT solutions in HRM. Special attention should be paid to high-tech enterprises conducting extensive research and development activities, and presenting a high level of innovation with highly qualified employees. Therefore, the objective of the study is to evaluate the use of information technologies in HRM in American high-tech enterprises. 


\section{Literature review}

New technologies support the recruitment and selection process since they allow the selection of the best candidate for a specific job position and assign tasks matching his or her competences. IT solutions enable collection and analysis of broader candidate information and streamline the selection process, since candidate information can be gathered and results obtained, along with a history of interviews and correspondence, all in one place. The IT tools are used in making decisions based on a combination of predictive results and a complex assessment (Stone et al., 2015, p. 219).

However, the extent to which these tools are used depends on the level of enterprise development. In American enterprises, $84 \%$ have used social media in recruitment (SHRM Survey Findings..., 2016, p. 3). Most often, this includes social networking services such as LinkedIn, Facebook, Twitter and discussion groups that bring together specialists from a given industry. The use of social networking sites by enterprises supports auxiliary processes (e.g. the improvement of internal communication between employees and clients) (Mastalerz, 2018, p. 81). Gamification, on the other hand, allows the verification of a candidate's knowledge and cognitive skills, and increases their involvement in solving situational judgement tests (Woźniak, 2015, p.19). This is most often used by representatives of the Y generation (Chamorro-Premuzic, 2015). The use of a wide range of IT tools enables the acquisition of employees with appropriate competences.

Gamification, as mentioned above, is used to motivate employees and is focused on rewarding and promoting behaviours that are positive for the company. This enables the modification of the behaviours and habits of users who interact with the processes carried out in a given company (Piotrkowski et al., 2015, p. 29).

Employee competence development has been increasingly supported by e-learning solutions. E-learning faces the largest decrease in participant engagement, however, thanks to gamification, their activity is greatly stimulated (Woźniak, 2015, p. 21). Moreover, the satisfaction of participating in such training positively correlates with the motivation to work (Stone et al., 2015, p. 219). In addition, employers encourage employees to develop their skills using educational platforms and learning management systems (LMS), which improve the effectiveness of training.

Currently, IT tools are used to support the employee evaluation process and provide detailed data on actions undertaken by a given employee, which enables the development of a relevant remuneration system. Additionally, they enable the monitoring and control of "unobservable" data in terms of the work-life balance, stress management, as well as data selection for launching and analysing individual performance evaluation, own work time planning, personal development and career management (Bondarouk \& Brewster, 2016, p. 2660). Gaining such detailed data provides action points aimed at increasing employee productivity.

The identification of, and providing opportunities for, development to talented employees is supported by IT tools. To search for talented employees in the environ- 
ment, social recruitment is used among group members on popular social networking sites, but also those for professionals, such as Quora. Talented employees are offered opportunities to learn in a formal and informal way, using such Web 2.0 tools as podcasts, teleconferences and vlogs (Meister \& Willyerd, 2010, p. 253). In addition, the apps used allow the combination of employee goals with broader organisational goals, which enhances their attachment to the organisation. Currently, enterprises consolidate IT solutions supporting talent management with other solutions by creating an integrated system (Sierra-Cedar, 2016-2017, p. 8).

The solutions used most frequently by enterprises are HR and payroll systems. They are used by $90 \%$ of enterprises and provide self-service options for employees and managers (Sierra-Cedar, 2016-2017, p. 8). Adoption of these systems facilitates HRM and simultaneously increases the latitude of employees. Furthermore, supervisors have access to necessary information about employees and can approve their applications. The HR department, on the other hand, can increase its efficiency through standardised procedures.

\section{Research methods}

This paper evaluates the use of information technologies for HRM in America's enterprises. Qualitative studies were conducted to illustrate the research problem in greater detail. This offered the opportunity to study respondents in their natural environment to achieve an in-depth understanding of the examined phenomenon (Czernek, 2016, p. 171). The research employed the case study method, which helps to understand and examine the processes of training activities in organisations (Noor, 2008 , p. 1602). This method provides a combination of different research methods (Flick, 2018, p. 108).

The objective of the study was to examine the use of IT tools in recruitment and selection, development and training, motivation, talent management and personnel services. The following research questions were put forward:

1. What IT tools are used by enterprises in recruitment and selection, development and training, motivation, talent management and personnel services?

2. What are the experiences related with these solutions?

A number of research techniques were used in the search for answers to the posed research questions. Based on a critical review of the literature, the research questions and survey questionnaire were developed. Moreover, for each enterprise, the author analysed the available documentation, conducted observations and interviews. These took the form of non-standardised, semi-structured and unstructured interviews. The results of the study were compiled on the basis of the analysis of three specific high-tech enterprises located in Silicon Valley, California (USA), from June 2015 to July 2016. Due to data protection regulations, the companies did not consent to have their names published. 


\section{Results}

Enterprise A develops personnel management software. The company hires 1,500 employees. The company implemented an integrated personnel management system which enabled employee performance evaluation, HR services, employee motivation, remuneration and employee self-service. The enterprise believes that data integration contributes to efficient employee management. The recruitment and selection process was supported by an IT solution using an applicant tracking system (ATS) that enabled a holistic approach to a candidate's occupational activity. In addition, a scorecard was used where a candidate's significant attributes were recorded. This facilitated the selection of a suitable employee. Big data analysis was conducted through a specially designed algorithm for indicating the demanded employee competences. It was important for the company to develop employee competences using e-learning and educational platforms. Moreover, an LMS was employed to support employee competence development.

Enterprise B develops electronic solutions for consumers, being a part of the Internet of Things (IoT) (collecting and processing data). The company hired 400 employees. A number of applications were tested for use in recruitment and selection. The selected application combined an ATS system and customer relationship management (CRM). The solution facilitated communication with candidates and enabled the acquisition of talented employees. For employee development, several education and e-learning platforms were applied. Employee performance was evaluated by an application linked with the remuneration system. Employees were satisfied with access to the solution that helped to solve problems and integrate people, processes and technologies. In addition, any employee could report a problem. HRM analytics was widely applied, contributing to the improvement of employee productivity. Moreover, employees who decided to leave the organisation completed an online questionnaire where they indicated reasons for their decisions. The questionnaires were subsequently analysed to improve the organisation. The introduction of an application supporting HR and payroll system management contributed to the significant improvement of employee management.

Enterprise $\mathrm{C}$ is an Artificial Intelligence laboratory hiring 16 employees. The company applied IT solutions in recruitment and talented employees were headhunted in discussion forums for professionals. Tools facilitating employee development (education and e-learning platforms, extensive e-book resources) were used most often because the continued advancement of knowledge and understanding the "bigger picture" are necessary in developing innovative solutions. To facilitate task allocation, a tool designed for teams of software programmers was employed. The tool supports planning and control of the development and implementation processes. Self-service HR application and gamification were employed to enhance employee engagement. The company used an application for employee performance 
evaluations; however, its use was discontinued. The company emphasised that due to its business profile, a direct contact with superiors, a joint determination of objectives and control of results are significant.

\section{Discussion}

Modern market demands have forced enterprises to pursue a new approach to HRM by using modern tools to increase their performance. High-tech enterprises deployed a wide range of IT tools in recruitment and selection, development and training, motivation, talent management and HR services, thus supporting personnel management processes and increasing the efficiency of administrative tasks. The type and scope of applied IT solutions depended on the size of the company. Large enterprises had a tendency to combine specific tools used in HR processes into one integrated employee management system, which facilitated the use of the data in different HRM processes. This was also confirmed by research results indicating that organisations are seeking integrated solutions (Sierra-Cedar, 2016-2017, p. 75).

Results of the conducted analysis show that the implementation of IT solutions in HRM produces certain limitations, since technologies can be static and information is transferred in one direction only. This results in the creation of distance between employees and has been addressed in the literature (Stone \& Deadrick, 2015, p. 140). Employees of the examined enterprises emphasised that they spend most of their time in front of a computer screen, therefore face-to-face relationships, opportunities for sharing opinions between employees and prospects for development are essential because this impacts their engagement.

\section{Conclusions}

The data analysis and observations allow one to formulate the following conclusions:

- the IT tools are especially important in the recruitment and selection process. Employees of HR departments stress that such tools help to conduct a more in-depth competence evaluation and retrieve candidate information from different sources to select the best candidates;

- employees of the examined companies emphasised that the high-tech sector demands ongoing competence development. Therefore, they were offered opportunities to broaden their knowledge, improve their skills and analytical capacities with the use of IT tools. Companies allocated significant funds for e-learning and educational platforms, and one enterprise has an LMS.

The companies pointed to a number of IT tool implementation advantages in HRM, such as improved HR management efficiency due to data integration, obtaining 
a better match between employee competences, their development capacities and company demands. Moreover, the use of IT tools increased employee engagement in the performance of their tasks. In the future, the development of existing technologies will enable the design of new work organisation forms, since IT solutions will be mobile and they will use big data processing that will enable working from different locations and efficient data integration.

The study had some limitations. The sample was composed of only three hightech companies from Silicon Valley; therefore, future research should provide for comparisons between different companies from different countries. Regarding the method used, a multiple case study method should be considered. Last, further research should be planned to explore the integration of IT solutions.

\section{References}

Bondarouk, T., \& Brewster, C. (2016). Conceptualising the future of HRM and technology research. International Journal of Human Resource Management, 27(21).

DOI: 10.1080/09585192.2016.1232296.

Bondarouk, T., Parry, E., \& Furtmueller, E. (2017). Electronic HRM: four decades of research on adoption and consequences. The International Journal of Human Resource Management, 28(1).

DOI: 10.1080/09585192.2016.1245672.

Bondarouk, T., \& Ruël, H. (2013). The strategic value of e-HRM: Results from an exploratory study in a governmental organization. International Journal of Human Resource Management, 24(2).

DOI: https://doi.org/10.1080/09585192.2012.675142.

Chamorro-Premuzic, T. (2015). 3 emerging alternatives to traditional hiring methods. Retrieved from $\mathrm{https} / / / \mathrm{hbr}$.org/2015/06/3-emerging-alternatives-to-traditional-hiring-methods [access: 20.10.2018].

Chmielarz, W., \& Parys, T. (2018). The use of mobile technologies in e-commerce. Annales Universitatis Mariae Curie-Sklodowska - sectio H, 52(2). DOI: 10.17951/h.2018.52.2.17-30.

Czernek, K. (2016). Wprowadzenie do badań jakościowych w naukach o zarządzaniu. In: W. Czakon (red.), Podstawy metodologii badań w naukach o zarządzaniu. Piaseczno: Wydawnictwo Nieoczywiste.

Flick, U. (2018). An Introduction to Qualitative Research. London: SAGE.

Kaufman, B.E. (2014). The historical development of American HRM broadly viewed. Human Resource Management Review, 24(3). DOI: https://doi.org/10.1016/j.hrmr.2014.03.003.

Mastalerz, M. (2018). Basics of estimating the costs of implementing social media portals in the enterprise. The use of mobile technologies in e-commerce. Annales Universitatis Mariae Curie-Skłodowskasectio $H, 52(2)$. DOI: 10.17951/h.2018.52.2.79-89.

Meister, J.C., \& Willyerd, K. (2010). The 2020 Workplace. How Innovative Companies Attract, Develop, and Keep Tomorrow's Employees Today. New York: HarperCollins.

Noor, K.B.M. (2008). Case study: A strategic research methodology. American Journal of Applied Sciences, 5(11). DOI: 10.3844/ajassp.2008.1602.1604.

Piotrkowski, K., Chmielewski, M., \& Ziółek, M. (2015). Grywalizacja jako technika zarządzania zasobami ludzkimi w firmie informatycznej. Przeglad Organizacji, 2.

SHRM Survey Findings: Using Social Media for Talent Acquisition - Recruitment and Screening. (2016). Retrieved from https://www.shrm.org/hr-today/trends-and-forecasting/research-and-surveys/Documents/SHRM-Social-Media-Recruiting-Screening-2015.pdf [access: 8.09.2018].

Sierra-Cedar. (2016-2017). HR Systems Survey. White Paper, $19^{\text {th }}$ Annual Edition.

Steiber, A., \& Alänge, S. (2016). The Silicon Valley Model: Management for Entrepreneurship. Springer International Publishing. DOI: 10.1007/978-3-319-24921-6. 
Pobrane z czasopisma Annales $\mathrm{H}$ - Oeconomia http://oeconomia.annales.umcs.pl Data: 26/04/2023 02:54:37

Stone, D.L., \& Deadrick, D.L. (2015). Challenges and opportunities affecting the future of human resource management. Human Resource Management Review, 25(2).

DOI: https://doi.org/10.1016/j.hrmr.2015.01.003.

Stone, D.L. et al. (2015). The influence of technology on the future of human resources management. Human Resource Management Review, 25(2). DOI: https://doi.org/10.1016/j.hrmr.2015.01.002.

Woźniak, J. (2015). Grywalizacja w zarządzaniu ludźmi. Zarządzanie Zasobami Ludzkimi, 2(103).

Zakrzewska-Bielawska, A. (2015). Strategie przedsiębiorstw w sieci. Wyniki badań firm high-tech. Prace Naukowe WWSZiP. Zarządzanie strategiczne, 32(2). 